\title{
MECHANICAL TRANSPLANTING OF GARLIC
}

\section{Abed El-Hameed, Sh.F.*}

\section{ABSTRACT}

This research aims to study the ability of garlic plant to be suitable for mechanical transplanting process under Egyptian conditions, for decreasing the plant stay period in the soil and decreasing the number of labors who used in traditional method. The performance of the used transplanter was carried out as function of change in transplanter forward speed, distance between seedlings and age of seedlings. The results illustrate that the garlic plant can be suitable to mechanical transplanting process, the seedling must be prepared in the basic soil, with seedling age of two months this tend to decrease the longitudinal scattering, transverse scattering and damaged seedling add to that the seedling depth was increased.

\section{INTRODUCTION}

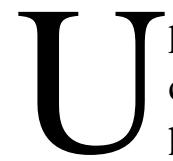

$\mathrm{p}$ till now, in Egypt the total area of garlic plants are still cultivated by traditional method (manually), that required the highest numbers of labors to cultivate in a short period which in return increase the cultivate costs. On the other hand, the problems of manual method were consuming more time, non - uniform of plant distribution and creating difficult conditions for mechanical harvesting operations. Hegazy 1990 indicated that. It is not surprising to learn that requiring about $(175$ - 210) men - hour to plant one feddan of transplanting onion manually. Harb et al., 1993 showed that the ground speed of $0.9 \mathrm{~km} / \mathrm{h}$ was suitable for operating the mechanical transplanter for planting pepper. Mansour 1997 found that by increasing the transplanted forward speed, both plant density and total yield decreased. Also, he added that the effective field capacity increased by increasing forward speed, but field efficiency decreased. Mohamed et al., 2000 mentioned that the total required cost for Holland and lanenn roulette transplanters was less than the total required cost for manual transplanting by 51.9 and $35.5 \%$ respectively.

\footnotetext{
*Agric. Eng. Res. Institute (MF), Dokki, Giza, Egypt.
} 
The value of actual field capacity at each level of transplanting forward speed did not affected by seedling spacing. The increasing in actual field capacity was only due to increasing transplanting forward speed. For two rested transplanters at $2.03 \mathrm{~km} / \mathrm{h}$ the actual field capacity was about 62 $\mathrm{fed} / \mathrm{h}$ while it was about $38 \mathrm{fed} / \mathrm{h}$ at $0.94 \mathrm{~km} / \mathrm{h}$ transplanting forward speed. Abdel-Aal et al., 2002 mentioned that theoretical and actual field capacity increased, while field efficiency decreased by increasing forward speed, also, they added that increasing row spacing increased field capacity and efficiency. Hegazy et al., 2003 mentioned that the increase of transplanting speed form had a significant effect on transplanting efficiency, this is due to high speed was always associated with high angular velocity of transplanting disc and this decreases the chance of finger (pocket) to catch the seedlings and resulting increase missed hills as the result of increase the damage and unfixed hills \%.The increase of forward speed form 0.55 to $1.6 \mathrm{~km} / \mathrm{h}$ lead to increase the actual field capacity form 0.12 to $0.32 \mathrm{fed} / \mathrm{h}$, decrease the efficiency form 85.7 to $80 \%$. The total consumed power during transplanter operation increased as the transplanter forward speed and planting depth increased, also indicated that by increasing transplanter forward speed from 0.55 to 1.6 $\mathrm{km} / \mathrm{h}$ the required energy increased. Helmy et al., 2003 showed that the use of transplanter under the lowest transplanting forward speeds gave better results. Under transplanting forward speed of $0.9 \mathrm{~km} / \mathrm{h}$ the field efficiency was $64.82 \%$ and values of longitudinal and transverse scattering were 0.39 and $1.08 \mathrm{~cm}$, respectively. The percentage of void seedlings was $10.5 \%$ and transplanter studding was $9.5 \%$.The results also revealed that, the power requirements increased and the energy requirements decreased with the increasing of machine forward speed.

The aims of this research are to:

-Study the ability of garlic plant transplanting under Egyptian condition. -optimize some different operating parameters affecting the performance of the transplanter (forward speed - distance between seedling).

\section{MATERIALS AND METHODS}

The field experiments were carried out through two consecutive seasons of 2010-2011, at center Awlad Saker, Sharkia Governorate, to evaluate 
the performance of hand feed vegetables transplanting machine for transplanting garlic comparing with traditional methods of seed garlic under Egyptian conditions. The mechanical analysis of the experimental soil was classified as a clay soil as shown in Table 1.

Table 1: The mechanical analysis of soil.

\begin{tabular}{|c|c|c|c|}
\hline \%fine sand & \%coarse sand & \%silt & \% clay \\
\hline 27.5 & 5.4 & 13.5 & 64.6 \\
\hline Soil texture & \multicolumn{3}{|c|}{ clay } \\
\hline
\end{tabular}

\section{Transplanting machine:}

The specifications of hand feed vegetable transplanting machine was shown in table 2 and figures 1and 2. The used hand feed plant transplanter type consists of two transplanting units connected with the frame and adjusted vertically to get the suitable distance between rows. Every transplanting unit consists of one furrow, 8 tweezers connected with periphery the disk packing wheels and seedlings box. The frame of machine attached by 3 Points hitch tool bar. Plant is placed manually into the transplanting tweezers.

\section{The agricultural tractor:}

The agricultural tractor was made in Romania, model D- 110, power 47.8 kW, crank shaft speed (1250 r.p.m), P.T.O shaft speed (540 r.p.m).

\section{The field experiments:}

All the experimental plots were carried out in all treatments due to the technical recommendations. The field experiments were carried out during two seasons by using seedlings to evaluate the performance, accuracy of seedling, power and energy and cost requirement for all operations of transplanting machine.

\section{The seeding preparation:}

To prepare seedling for manual and mechanical transplanting process, two methods were used:

a- Cultivated stones in basic soil. 
Table 2. Specifications of transplanting machine:

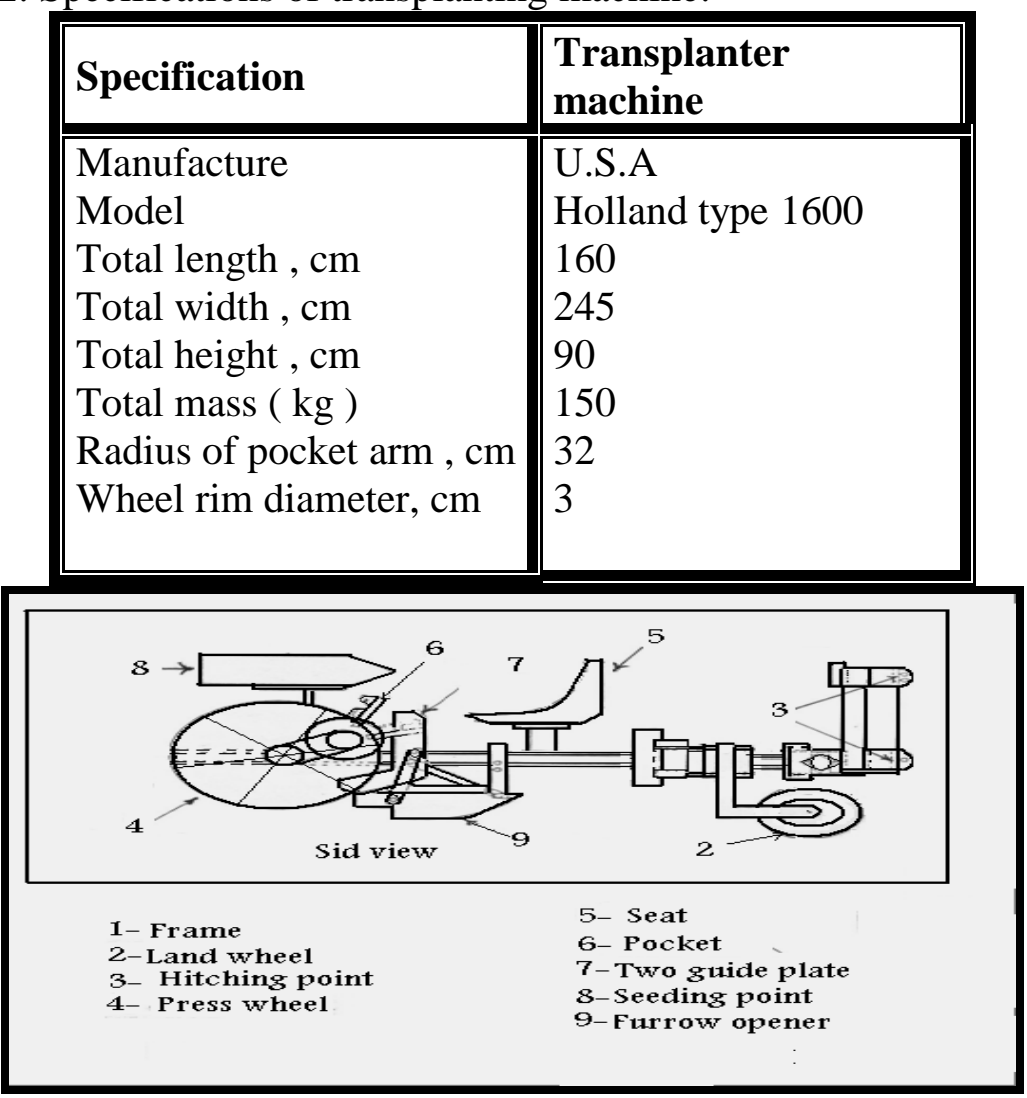

Figure 1.Layout of hand feed transplanter.

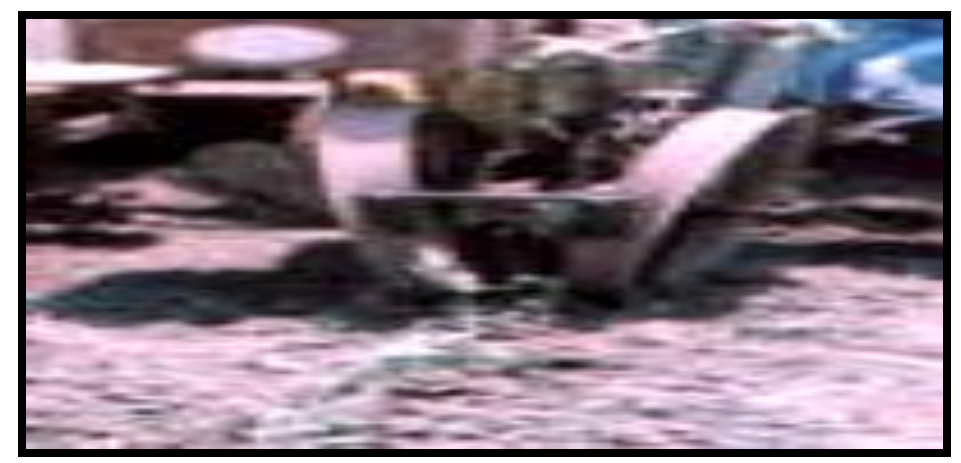

Figure 2.The transplanter in the field.

b- Cultivated stones in plates: The depth soil which put in plates to cultivate stones were $(2.5,5$, and $7.5 \mathrm{~cm})$ to equipment the seedling. 


\section{Treatments and experimental design:}

The experimental design which was used in this work (split-split plot design). It is shown in Table 3.

Table 3. The distribution of treatments in field.

\begin{tabular}{|c|c|c|c|c|c|c|c|c|c|c|c|c|c|c|c|c|}
\hline \multirow[b]{2}{*}{ t. } & \multicolumn{4}{|c|}{$S_{1}$} & \multicolumn{4}{|c|}{$\mathrm{S}_{2}$} & \multicolumn{4}{|c|}{$\mathrm{S}_{3}$} & \multicolumn{4}{|c|}{$S_{4}$} \\
\hline & $\mathrm{d}_{1}$ & $\mathrm{~d}_{2}$ & $\mathrm{~d}_{3}$ & $\mathrm{~d}_{4}$ & $\mathrm{~d}_{1}$ & $\mathrm{~d}_{2}$ & $\mathrm{~d}_{3}$ & $\mathrm{~d}_{4}$ & $\mathrm{~d}_{1}$ & $\mathrm{~d}_{2}$ & $\mathrm{~d}_{3}$ & $\mathrm{~d}_{4}$ & $\mathrm{~d}_{1}$ & $\mathrm{~d}_{2}$ & $\mathrm{~d}_{3}$ & $\mathrm{~d}_{4}$ \\
\hline $\mathrm{A}_{1}$ & & & & & & & & & & & & & & & & \\
\hline $\mathrm{A}_{2}$ & & & & & & & & & & & & & & & & \\
\hline $\mathrm{A}_{3}$ & & & & & & & & & & & & & & & & \\
\hline $\mathrm{A}_{4}$ & & & & & & & & & & & & & & & & \\
\hline
\end{tabular}

$\mathrm{S}=$ seedling forward speed $\left\{\mathrm{s}_{1}=1, \mathrm{~s}_{2}=1.25, \mathrm{~s}_{3}=1.5, \mathrm{~s}_{4}=1.75 \mathrm{~km} / \mathrm{h}\right\}, \mathrm{d}$ $=$ seedlings distances in the raw $\left\{d_{1}=10, d_{2}=15, d_{3}=20, d_{4}=25 \mathrm{~cm}\right\}$ and $A=$ ages of transplanting $\left\{A_{1}=30, A_{2}=45, A_{3}=60\right.$, and $A_{4}=75$ days .

\section{Seedling experimental area:}

The transplanting area was about 2 feddans divided to 66 equal plots at dimensions of $(2.5 \times 50 \mathrm{~m})$, two plot to manual transplanting (seedling and stone) and (64 plot) to mechanical transplanting.

\section{Measurements:}

For recording the observations in all studied characteristics, four samples, each of $5.0 \mathrm{~m}$ length were selected randomly from each treatment and the data were recorded after 21 days from the transplanting date.

\section{The longitudinal and transverse scattering:}

Deviation in the longitudinal and transverse direction from the average distance of 5 meters along the transplanted for each mechanical and manual transplanting method were determined by using the following equation;

$C . V=\frac{s d}{\bar{X}} \times 100$

$s d=\sqrt{\frac{\sum \mathrm{X}^{2}-(\Sigma \mathrm{X})^{2} / n}{n-1}}$

Where:

sd $=$ Standard deviations, $X=$ Distance between seedlings in the row, $\mathrm{cm}, \bar{X}=$ Mean distance between seedlings in the row at longitudinal 
scattering, and mean distance between seedlings at left and right center line in transverse scattering, $\mathrm{cm}, \mathrm{n}=$ number of observations, $\Sigma \mathrm{x}=$ summation of the distance between hills on row and $\Sigma X^{2}=$ summation of the square distance between hills on row. The coefficient of variation between $10 \%$ and $20 \%$ is considered excellent generally and acceptable for must field application as reported by Coates, 1992.

\section{Seedling depth:}

Ten seedlings were pulled out randomly from the soil and measured the seedling depth.

\section{Damaged seedlings percentage:}

Damaged seedlings percentage was calculated by using the following formula according to Hossary et-al, 1980.

$$
D_{S}=\left(\frac{N_{d}}{N_{t h}}\right) \times 100
$$

Where:

$\mathrm{D}_{\mathrm{s}}=$ Damaged seedlings $\%, \mathrm{~N}_{\mathrm{d}}=$ Number of damaged seedlings $/ \mathrm{m}^{2}$ and $\mathrm{N}_{\mathrm{th}}=$ theoretical number of seedlings $/ \mathrm{m}^{2}$

\section{A void seedlings:}

The percentage of avoid seedlings was calculated according to Hossary et-al, 1980 by using the following formula:

$$
V_{S}=\left(\frac{N_{V}}{N_{t h}}\right) \times 100
$$

Where:

$V_{s}=$ A void seedlings percentage, $N_{V}=$ Number of void seedlings $/ \mathrm{m}^{2}$ and $N_{t h}=$ theoretical number of seedlings $/ \mathrm{m}^{2}$.

\section{Plant density:}

The average plant density (plant $/ \mathrm{m}^{2}$ ) was measured after transplanting for each transplanting method by counting the number of theoretical seedlings in unit area minus defective and damage seedlings. 


\section{The field capacity and efficiency:}

The theoretical effective field capacity and efficiency were determined as the following.

$$
F_{t h}=\frac{S \times W}{4200}
$$

Where:

$\mathrm{F}_{\text {th }}=$ theoretical field capacity, fed $/ \mathrm{h}, \mathrm{S}=$ forward speed, $\mathrm{km} / \mathrm{h}$ and $\mathrm{W}=$ Transplanter width, $\mathrm{m}$.

\section{- The actual field capacity:}

The actual field capacity is calculated as follows Abd. EL-Aal, et al., 2002.

$$
F_{a c t}=\frac{60}{t_{u}+t_{i}}
$$

Where:

$F_{a c t}=$ actual field capacity, fed/h, $t_{u}=$ the utilized time /fed, min. and $t_{i}=$ the summation of lost times /fed, min.

\section{-Field efficiency:}

The field efficiency is calculated by using the following formula:

$$
\eta_{f}=\frac{F_{a c t}}{F_{t h}} \times 100
$$

Where:

$\eta_{f}=$ Field efficiency, \%., $F_{a c t}=$ Actual field capacity, fed $/ \mathrm{h}$ and $F_{t h}=$ Theoretical field capacity, fed/h.

\section{Human energy:}

For each operation the consumed human energy $\left(E_{H}\right)$ was estimated based on the power of one laborer, which considered being about $0.1 \mathrm{hp}$, using the following equation of chancellor, 1981.

$$
E_{H}=\frac{0.1 \times 0.0746 \times N_{l}}{F_{\text {act }}} \ldots . . .(\mathrm{kW} . \mathrm{h} / \mathrm{fed})
$$

Where:

$N_{l}=$ number of laborers, man, $\quad F_{a c t}=$ Actual field capacity, fed $/ \mathrm{h}$, $0.0746=$ coefficient of changing from $\mathrm{hp}$ to $\mathrm{kW}$ and $\quad 0.1=\mathrm{hp}$ of agricultural laborer, hp/fed. 


\section{Energy requirement:}

Estimation of the required energy $\left(E_{R}\right)$ for different mechanical transplanting treatments was calculated by using the following equation Embapy, 1985:

$$
E_{R}=\left(F c \times \frac{1}{3600}\right) \times \frac{\rho \times L . C . V \times 427 \times \eta_{t h} \times \eta_{m}}{75 \times 1.36 \times F_{a c t}}(\mathrm{~kW} . \mathrm{h} / \mathrm{fed})--(9)
$$

Where:

Fc $\quad=$ Fuel consumption, $\mathrm{L} / \mathrm{h}, \rho=$ Density of the fuel, $0.85 \mathrm{~kg} / \mathrm{L}$. for diesel, L.C.V = Lower calorific value of fuel, average L.C.V of fuel is $10000 \mathrm{k} \mathrm{cal} / \mathrm{kg}, 427=$ Thermo-mechanical equivalent, $\mathrm{Kg} \mathrm{m} / \mathrm{kcal}, \eta_{\mathrm{th}}=$ thermal efficiency of engine, $40 \%$ for diesel engine, $\eta_{\mathrm{m}}=$ Mechanical efficiency of engine, $80 \%$ for diesel engine and $F_{\text {act }}=$ Actual field capacity, fed/h.

\section{Hourly cost:}

The following equation of Awady, 1978 was taken into account to the cost per hour for two different types of transplanting machines:

$$
C=\frac{P}{h}\left(\frac{1}{L}+\frac{i}{2}+a+r\right)+(0.9 W \times F \times U)+b
$$

Where: $\mathrm{C}=$ Cost per hour of operation. L.E $/ \mathrm{h}, \mathrm{P}=$ Estimated price of the machine L. E, h = Estimated yearly hours operation, $450 \mathrm{~h}, \mathrm{~L}=$ Life expectancy of the machine, 10 years, $\mathrm{i}=$ Annual interest rate, $10 \%$, $\mathrm{a}=$ Annual taxes and overheads, $2 \%, \mathrm{r}=$ Annual repair and maintenance rate, $18 \%, 0.9=\mathrm{A}$ correction factor for rated load ratio and lubrication, $\mathrm{w}=$ Engine power, $\mathrm{hp}, \mathrm{F}=$ Specific fuel consumption L/hp.h, $\mathrm{U}=$ Fuel price $\mathrm{L} . \mathrm{E} / \mathrm{L}$ and $\mathrm{b}=$ Hourly labor wage $\mathrm{L} . \mathrm{E} / \mathrm{h}$.

\section{The production costs:}

It was used to compare the production per ton for manual and mechanical transplant and can be calculated as follows:-

$$
p . c=\frac{C}{R \times P}
$$

where:

p.c $=$ production costs, L.E/fed., $\quad \mathrm{C}=$ hourly costs, L.E/h, $\mathrm{R}=$ Performance rate, fed/h, $\mathrm{P}=$ production rate, ton/fed. 


\section{RESULTS AND DISCUSSION}

\section{The seedling preparation seeding:}

Figures 3 and 4 illustrated the seedlings which cultivated in plates for one month gave normal seedlings but the seedlings which cultivated in basic soil for 30 to 75 day gave strong seedlings compared with the seedling which cultivated in plates under different depths of $(2.5,5$, and $7.5 \mathrm{~cm})$ .So, the basic soil was the best method to prepare seedlings.

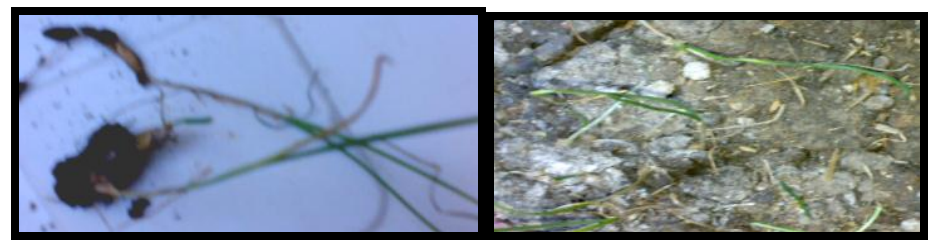

Figure 3.The shape of seedling which cultivated two months ago in plates

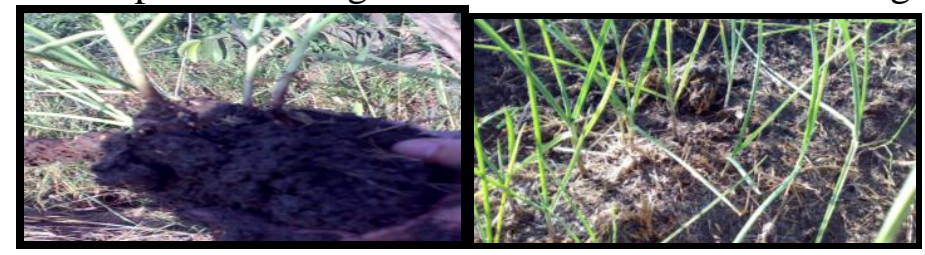

Figure 4.The shape of seedling which cultivated two months ago in basic soil

\section{Longitudinal scattering seedlings:}

Figure 5 indicated that, increasing transplanting forward speed increased the coefficient of variation values of longitudinal scattering for transplanting garlic crop. Too, increasing seedling distances in the row decreased the coefficient of variation values at the same previous conditions. The highest and lowest values of coefficient of variation for the longitudinal scattering which were $16.11 \%$ and $7.83 \%$ at forward speed of $(1.75$ and $1.0 \mathrm{~km} / \mathrm{h})$ and seedling distances of $(10$ and $25 \mathrm{~cm})$. Worth mention by increasing age of seedling the coefficient of variation decreased by $2.3 \%$. In addition that the coefficient of variation for manual method was $13.89 \%$ at average seedling distance of $17.5 \mathrm{~cm}$.

\section{Transverse scattering of seedlings:}

Figure 6 indicated that, increasing transplanting forward speed increased the coefficient of variation of transverse scattering by $5.9 \%$. On opposite that, increasing age seedling decreased the coefficient of variation of 
transverse scattering by $1.7 \%$. While, increasing seedling distances in the row decreased the coefficient of variation of transverse scattering by $2.24 \%$ at the same previous conditions. Too, the results illustrated that the value of the coefficient of variation transverse scattering for manual method was $14.6 \%$.

\section{Seedlings depth:}

Figure 7 indicated that, increasing transplanting forward speed was followed with decrease in seedling depth by $28.21 \%$ but, increasing seedling age the seedling depth increased by $9.8 \%$. This was due to increase the put time of seedling and seedling weight. Also, the results illustrated that the values of seedling depth for manual method decreased by $25.2 \%$ compared with mechanical method.
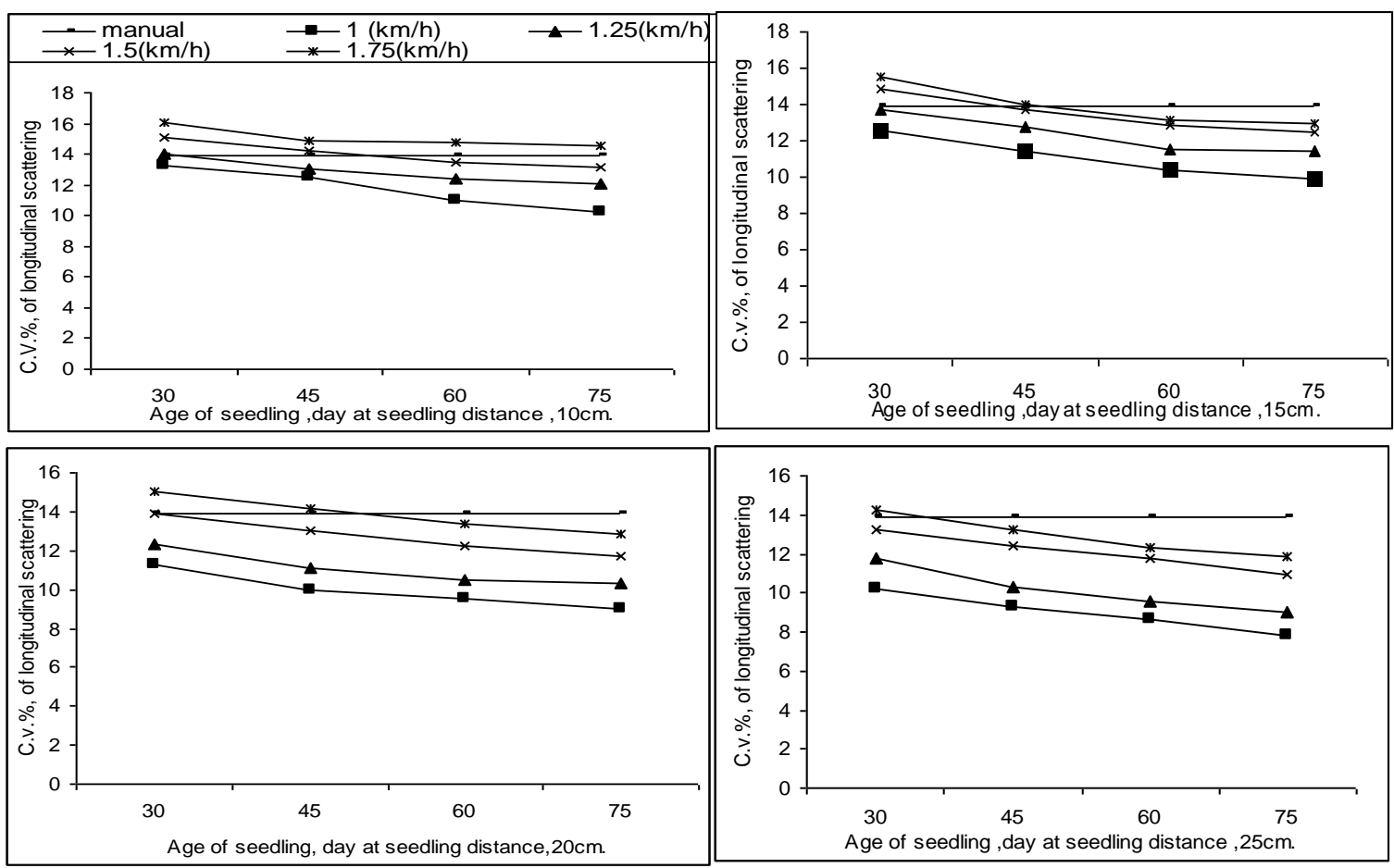

Figure 5. Effect of different forward speeds, seedling age and seedling distance on longitudinal scattering. 
FARM MACHINERY AND POWER
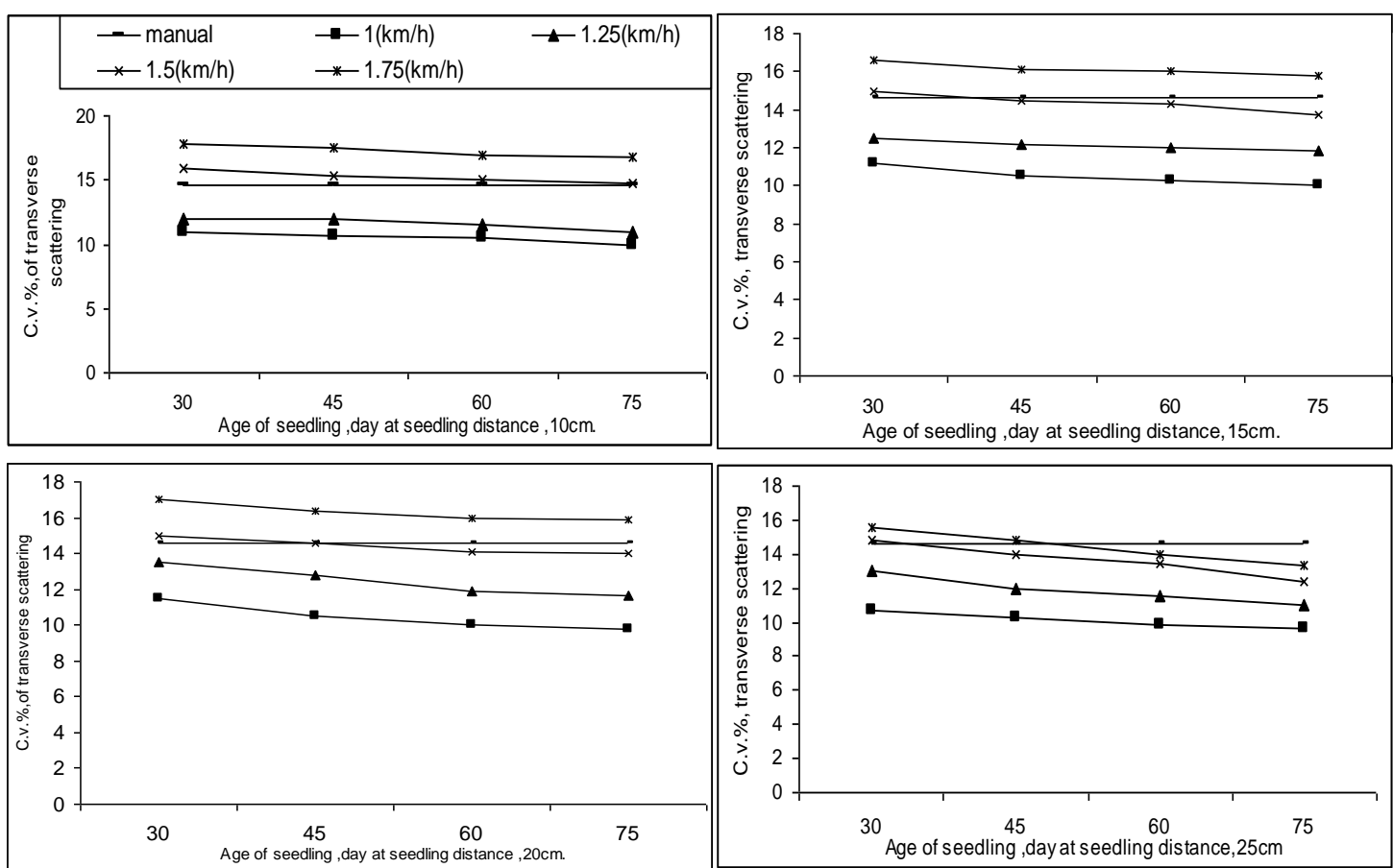

Figure 6. Effect of different forward speeds, seedling age and seedling distance on transverse scattering.
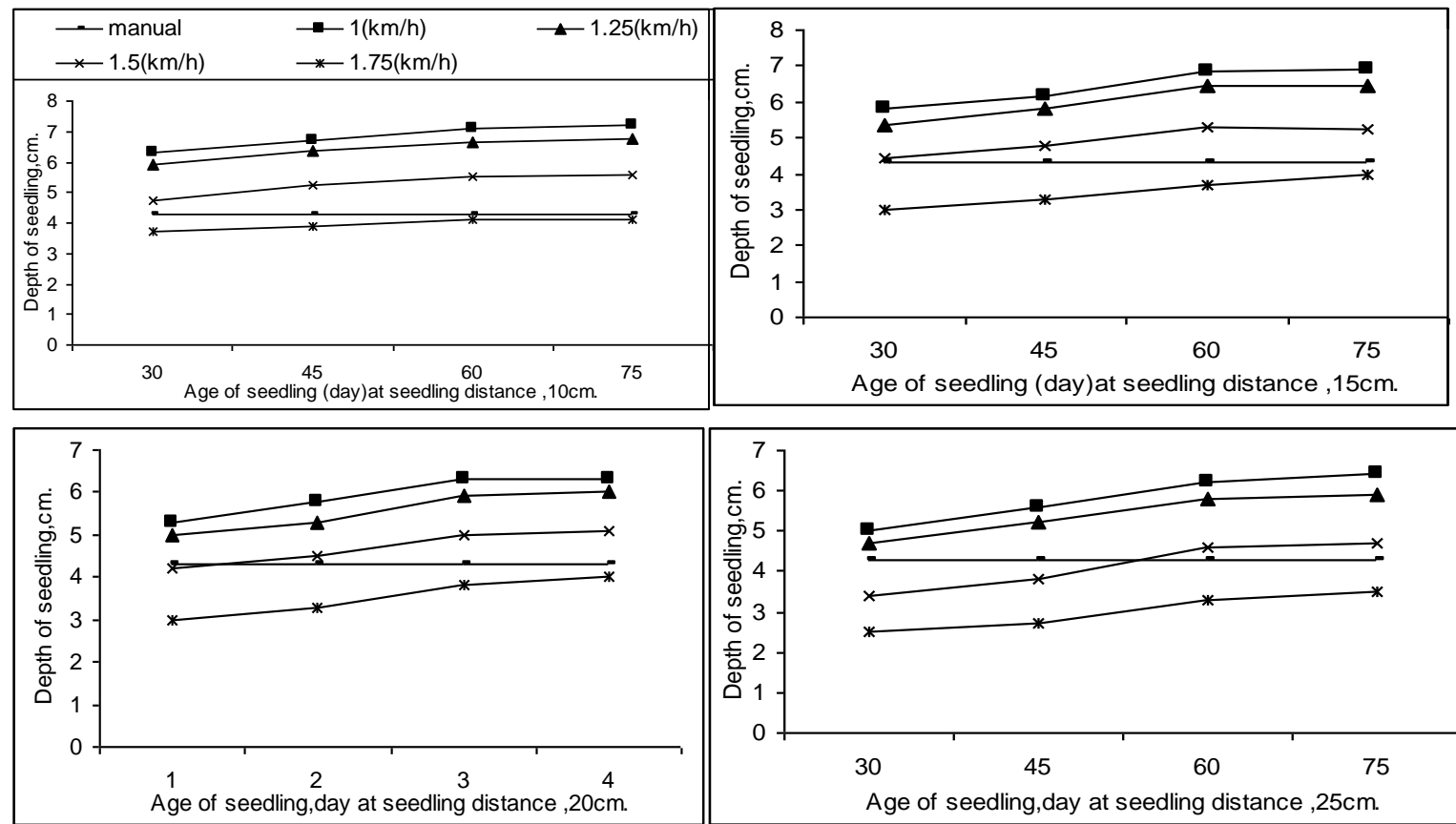

Figure7. Effect of different forward speeds, seedling age and seedling distance on seedlings depth. 


\section{A void seedlings:}

Figure 8 indicated that, increasing transplanting forward speed caused increase in a void seedling for transplanting by average value of $1.46 \%$. While, increasing seedling distances in the row decreased a void seedling at the same previous conditions by average value $0.26 \%$. This was due to the increase of transplanter forward speed, so the labor can not feed seedling in the pocket. But, by using manual method, the average a void seedling was $1.22 \%$ at average seedling distance of $21.5 \mathrm{~cm}$.

\section{The seedlings damage:}

Figure 9 indicated that, increasing transplanting forward speed increased the seedlings damaged for transplanting garlic crop by average value $1.34 \%$. While, increasing seedling distances in the row decreased the seedlings damaged at the same previous conditions by average value $0.62 \%$. Worth mention the increasing of seedling age decreased the seedling damaged by average $1.37 \%$. Added to that the maximum value of seedling damage $4.8 \%$ was notice under forward speed $1.75 \mathrm{~km} / \mathrm{h}$ and seedling age 75 day. But the seedlings damaged for manual method was $4.2 \%$.

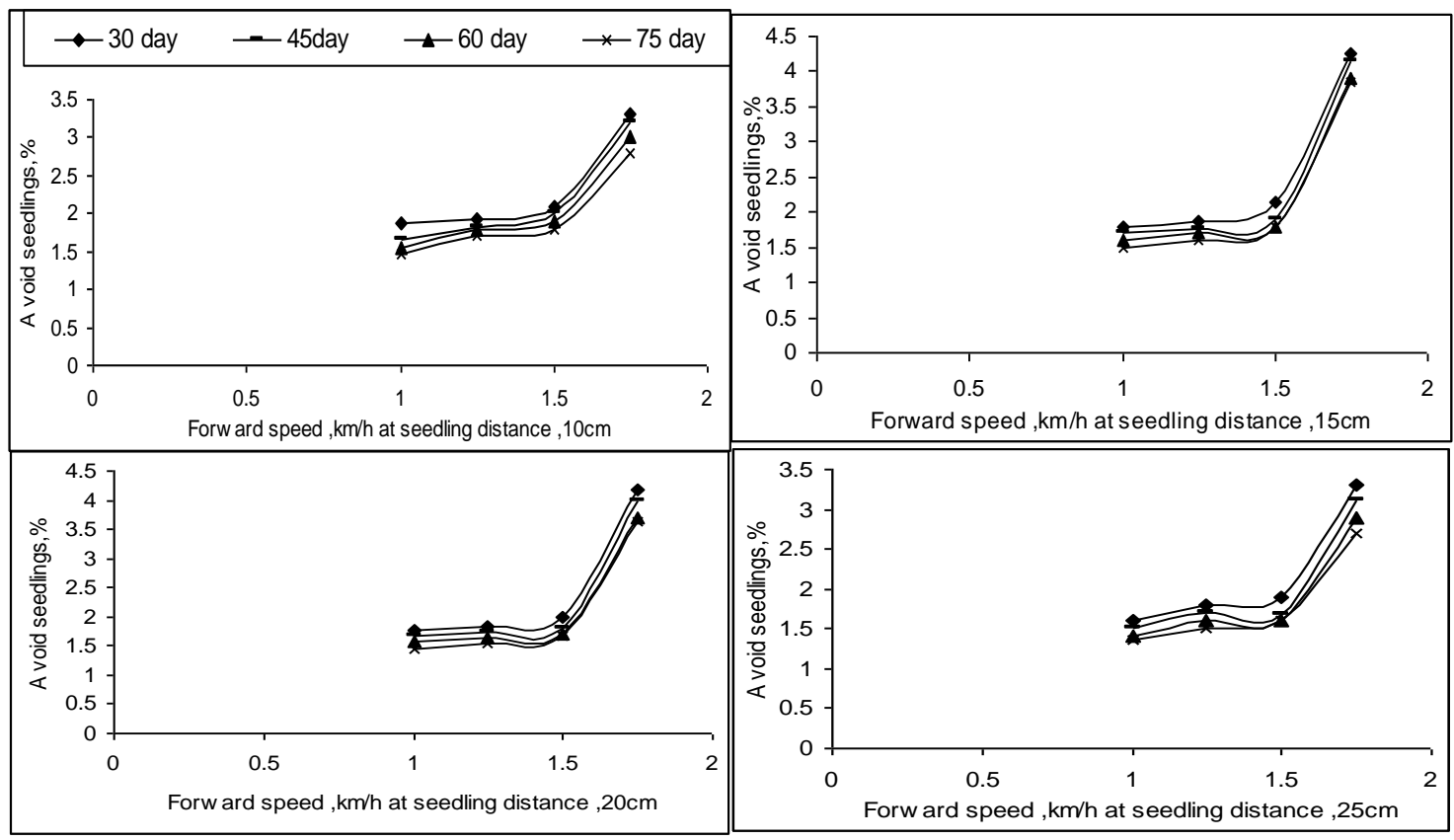

Figure 8. Effect of different forward speeds, seedling age and seedling distance on a void seedling. 

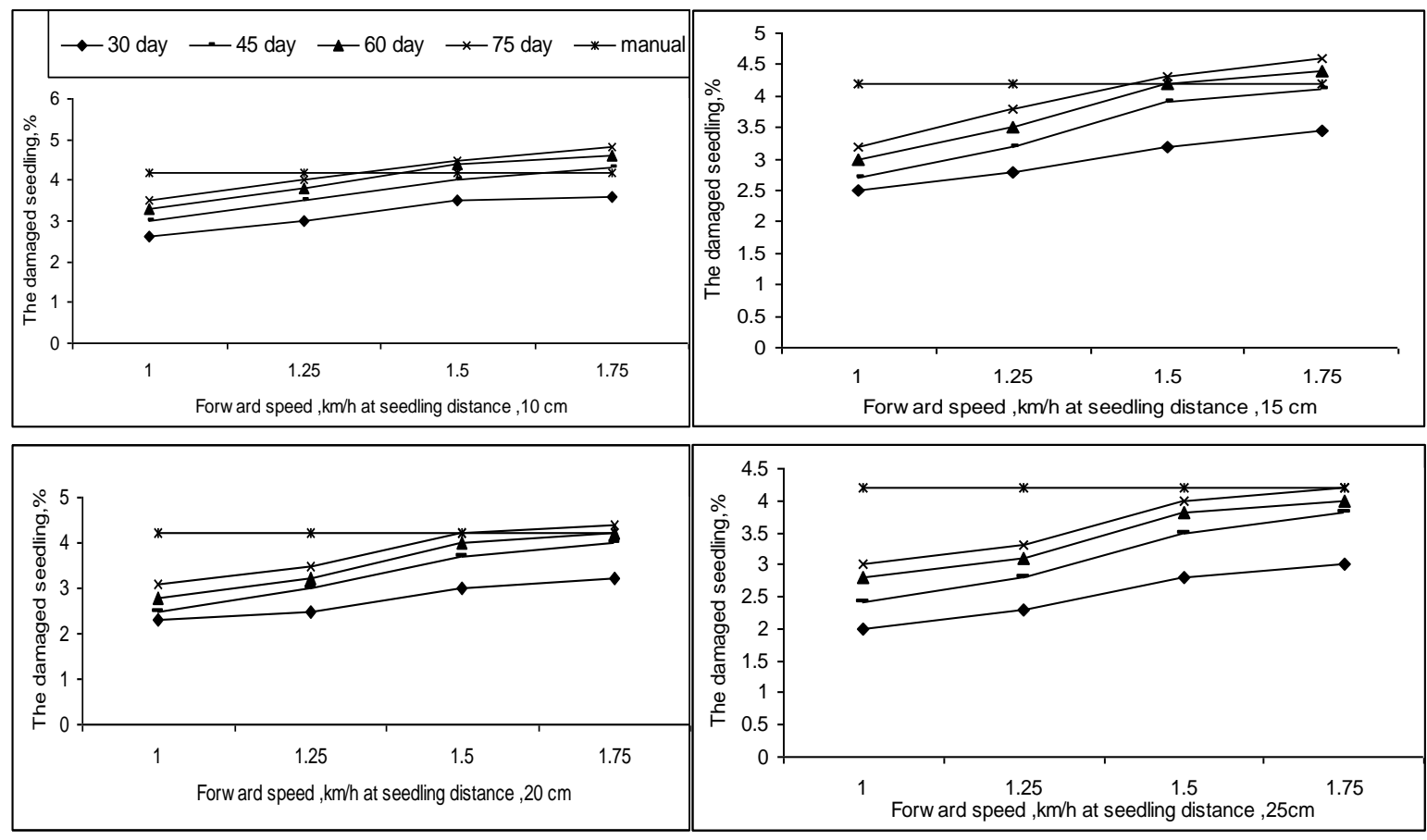

Figure 9. Effect of different forward speeds, age seedling and seedling distance on the damage seedling.

\section{The number of seedlings per meter square $\mathbf{m}^{2}$ :}

Figure 10 indicated that increasing transplanting forward speed and seedling distances in the row decreased the number of seedlings per square meter by 3.9 and $6.6 \%$ respectively.The results referred to, by increasing seedling age to 60 days the number of seedlings per meter square increased by $9.2 \%$, in the opposite that this value was decreases by using seedling age 75 day by $13.7 \%$ and manual method by $23.4 \%$.

8. Statistical analysis: The statistical analysis had a high significant effect of seedling forward speed, seedling distances and seedling age on seedling depth avoid seedlings. But there were non significant of forward speed with seedling distance, forward speed with seedling age and forward speed, seedling distance with seedling age on a void seedling and number of seedling. This was due to the effect of high forward speed so, the high speeds were not recommended to garlic transplanting these data shown in table 4 . 

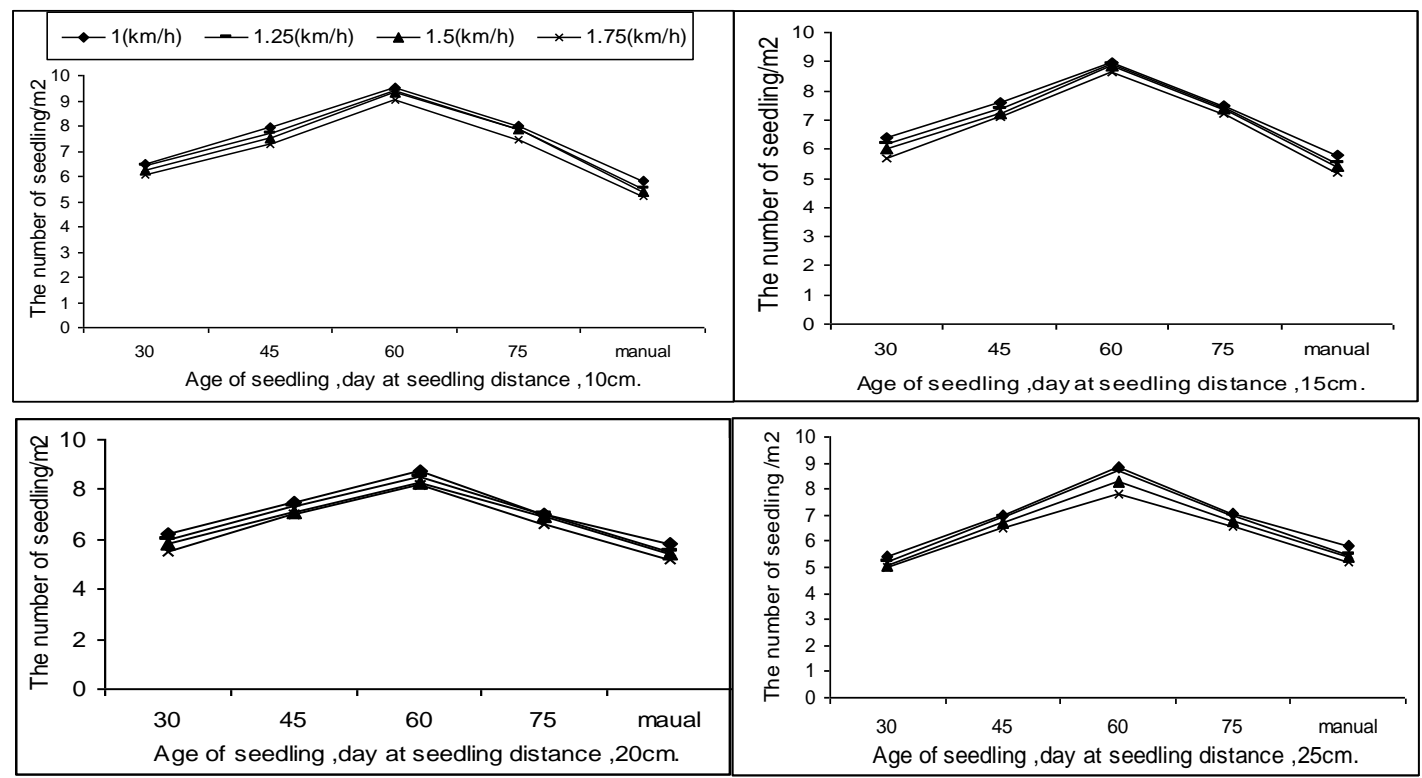

Figure 10. Effect of different forward speed, seedling age and seedling distance on number of seedling per $\mathrm{m}^{2}$.

Table 4: ANOVA analysis of seedling.

\begin{tabular}{|c|c|c|c|c|c|c|}
\hline \multirow[b]{2}{*}{ Measurements } & \multicolumn{6}{|c|}{ Treatments } \\
\hline & $\mathbf{A}$ & B & $\mathbf{C}$ & $A$ and $B$ & $A$ and $C$ & $A, B$ and $C$ \\
\hline Seedling depth & ** & ** & ** & ** & 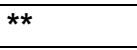 & $\star *$ \\
\hline Avoid seedlings & $\star \star$ & ** & $\star \star$ & ns & ns & ns \\
\hline Seedlings damage & $\star \star$ & $\star \star$ & ** & * & * & * \\
\hline Number of seedling/m $\mathrm{m}^{2}$ & ** & $\star \star$ & ** & ns & ns & ns \\
\hline
\end{tabular}

$\mathrm{A}=$ Forward speed, $\mathrm{km} / \mathrm{h} \quad \mathrm{B}=$ Seedlings distances, $\mathrm{cm} \quad \mathrm{C}=$ seedling age, day $\quad * *=$ highly significant at a level of $1 \%, *$ = significant at a level of $1 \%$; ns, non significant

\section{Field capacity and field efficiency:}

Table 5 show that, by increasing forward speed the field efficiency increased by average $1.6 \%$. Added to that by increasing forward speed the field efficiency was decrease.

Table 5: Field capacity and field efficiency for transplanting garlic crop.

\begin{tabular}{|c|c|c|}
\hline $\begin{array}{c}\text { Transplanter forward speed, } \\
\mathbf{~ k m} / \mathbf{h}\end{array}$ & $\begin{array}{c}\text { Actual field capacity } \\
\text { Fed/h }\end{array}$ & $\begin{array}{c}\text { Field efficiency } \\
\mathbf{\%}\end{array}$ \\
\hline \hline 1.00 & 0.44 & 76.5 \\
\hline 1.25 & 0.54 & 74.6 \\
\hline 1.50 & 0.63 & 72.1 \\
\hline 1.75 & 0.73 & 71.5 \\
\hline
\end{tabular}




\section{Energy requirements:}

Table 6 shows the actual demands of energy in kW.h/fed for transplanting garlic, the values of energy was decreased by increasing forward speed. The increasing of forward speed decreased the total demand of energy by average $4.6 \mathrm{~kW} . \mathrm{h} /$ fed.

Table 6: The actual demands of energy in kW.h / fed for transplanting garlic.

\begin{tabular}{|c|c|c|c|c|c|c|}
\hline $\begin{array}{c}\text { Transplanting } \\
\text { Forward } \\
\text { speed, km/h. }\end{array}$ & $\begin{array}{c}\text { Fuel } \\
\text { consump. } \\
\text { L/h. }\end{array}$ & $\begin{array}{c}\text { Number } \\
\text { of } \\
\text { laborers }\end{array}$ & $\begin{array}{c}\text { Actual field } \\
\text { capacity } \\
\text { fed/h }\end{array}$ & $\begin{array}{c}\text { Human } \\
\text { energy, } \\
\mathbf{k W . h} / \mathbf{f e d}\end{array}$ & $\begin{array}{c}\text { Mechanical } \\
\text { Energy, } \\
\mathbf{k W . h} / \mathbf{f e d}\end{array}$ & $\begin{array}{c}\text { Total } \\
\text { demand } \\
\text { of energy } \\
\mathbf{k W . h} / \mathbf{f e d}\end{array}$ \\
\hline \hline 1.00 & 6.08 & 3 & 0.44 & 0.047 & 43.66 & 43.71 \\
\hline 1.25 & 6.26 & 3 & 0.54 & 0.039 & 36.30 & 36.34 \\
\hline 1.50 & 6.53 & 3 & 0.63 & 0.033 & 32.70 & 32.73 \\
\hline 1.75 & 6.88 & 3 & 0.73 & 0.029 & 29.82 & 29.84 \\
\hline
\end{tabular}

\section{Transplanting cost analysis:}

Figure 11 shows that the highest value of transplanting cost with manual method was $360 \mathrm{LE} / \mathrm{fed}$ and the lowest value with mechanical transplanting was 54.2 LE/ fed. with transplanting forward speed of 1.75 $\mathrm{km} / \mathrm{h}$. This data illustrated that by using mechanical method, the saved costs per feddan was $77.3 \%$.

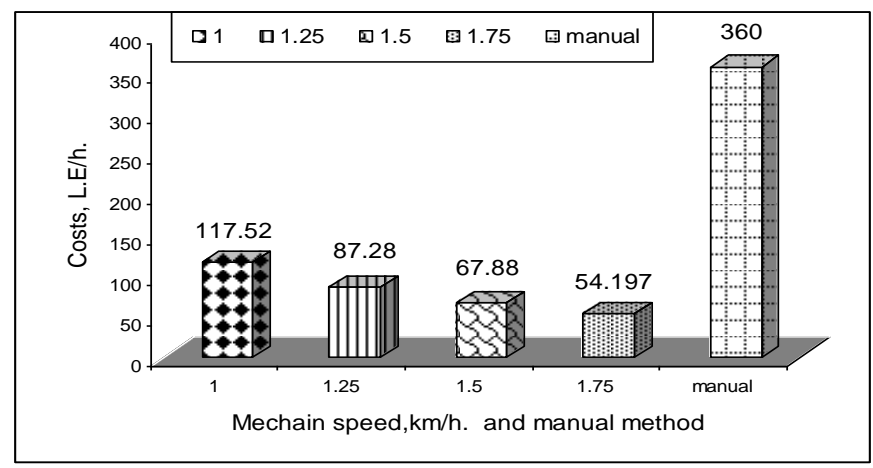

Figure 11.Cost analysis of transplanting methods.

\section{The production costs:}

Figure 12 shows the production costs per ton for manual and mechanical transplanting and stones cultivating. Mechanical transplanting save the cost by average $88.7 \%$ and $80.9 \%$ compared with manual transplanting and stone cultivation. 


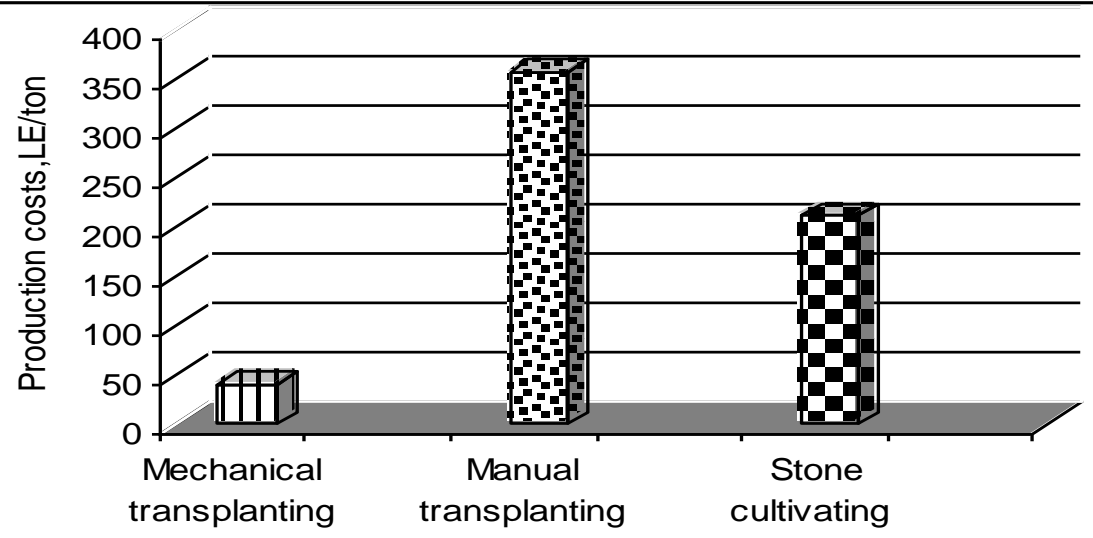

Figure 12.The production costs of transplanting methods and stones cultivating.

\section{CONCLUSION}

The soil basic was the best method to prepare seedlings. The increasing of transplanting forward speed increased the coefficient of variation of longitudinal scattering and transverse scattering by $9.7 \%$.and $5.9 \%$. In opposite, the increasing of transplanting forward speed decreased the seedling depth by $28.21 \%$. Too, the results illustrated that the values of seedling depth for manual method decreased by $25.2 \%$ compared with mechanical method. The increasing of transplanting forward speed increased the a void seedling for transplanting by average value $1.46 \%$. While, the increasing of seedling distances in the row decreased a void seedling at the same previous conditions by average value $0.26 \%$. But, the increasing of seedling age decreased the damaged seedling by average $1.37 \%$. Worth mention the best results were shown under used seedling ages 60 days this was due to increase in seedlings number per square meter by $9.2 \%$. Too, the results shown that, by increasing forward speed the field efficiency increased by average 5.9\%.Add to that the increasing of forward speed decreased the total demand of energy by average 4.6 kW.h / fed. Too, the results illustrated that by using mechanical method save the costs per feddan by $77.3 \%$ compared with manual method. Too, the mechanical transplanting save the production costs by average $88.7 \%$ and $80.9 \%$ compared with manual transplanting and stone cultivation. 


\section{REFERENCES}

Abdel El-Aal , A-E , S.L- Badr ; and A- lotfy ( 2002). Consumed energy for transplanting of some vegetable, Misr. J. Ag. Eng., 19(3) PP 657-667.

Chancellor, W.I. (1981): Substituting information for energy in agriculture. Trans. ASAE, (5): 802-807.

Coates, W. (1992). Performance evaluation of a pendulum spreader. Trans. ASAE, 8(3):285-288.

El- Awady, M. N. (1978): "Engineering of tractors and agricultural machinery"(Arabic) Textbook. Agric, Ean shams univ: 289.

Embaby, A. T. (1985). A comparison of different mechanization system for cereal production. M.Sc. Thesis, Agric. Eng., Cairo University.

Harb, S-K.; H.A.Abdel - mawla and G.M. Salama (1993). "Comparison between mechanical and manual transplanting of tomato" Minia J. of Ag.Res. And Dev. (special issue). 15, (1): 361375.

Hegazy, S.E.K, (1990). Mechanization of onion planting M.S.C. Thesis Ag.,Mech. Dept., Fec. Of Ag., Univ. of Mansoura.

Hegazy, K.S; A.E. Ahmed; M.A.A. Mady and B. A Hemeda (2003)."Response of swee potato to mechanical transplanting" Misr J. Ag. Eng., 20(2):325-338.

Helmy; M.A; S.M. Gomaa and I.B yousef (2003). "Distribution uniformity of mechanical transplanting of pepper." Misr. J. Ag. Eng. January 20 (1) pp 64 - 71.

Hossary, A. M; N.M. EL- Awady; A. I. Hashish and A.EL-Beheriy (1980). Rice transplanting. Zagazig Univ. Fac. of Agric., Mech. Dept., Res. Bul. No.,154, pp.9- 15.

Mansour, N.A (1997). "A Study on mechanical planting of onion crop." M.Sc. Thesis, Ag. Mech. Dept., fac. of Ag., Univ. of Tanta.

Mohamed, M.A; N.A. Srour and M. A. Abo-amera (2000). "Performance of semi-automatic transplanters in transplanting tomato." Misr J.Ag- Eng.17 (3):469- 482. 


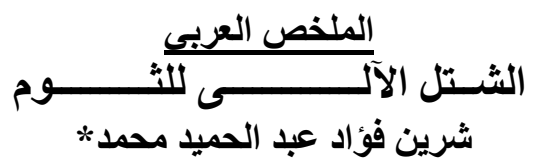

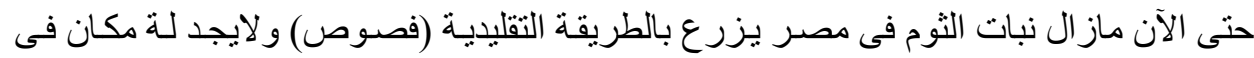

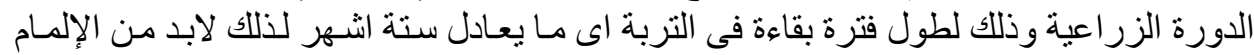

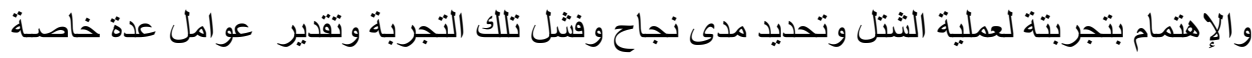

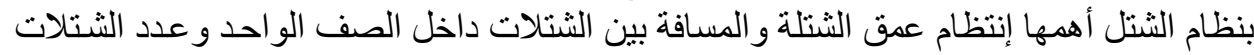

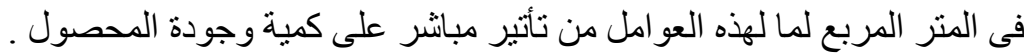

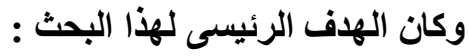

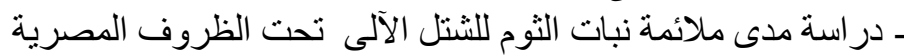

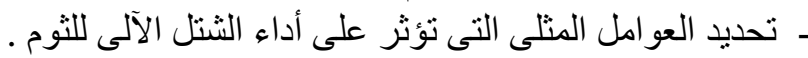
اعداد الثتلات

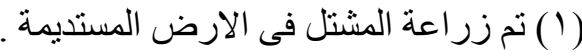

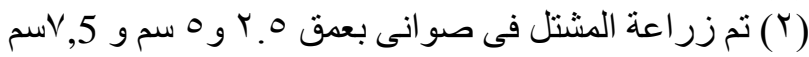

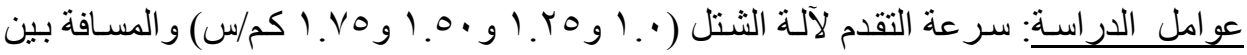

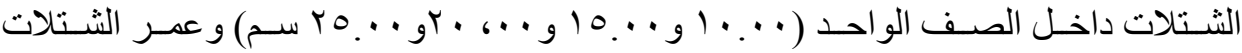

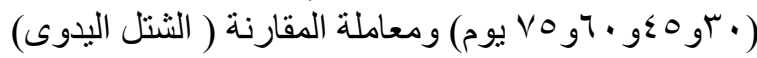

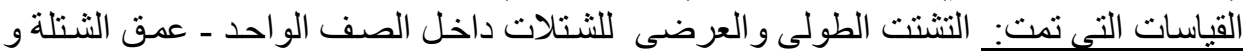

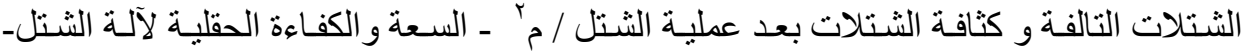
متطلبات الطاقة لعملية الثتل الآلى_ متطلبات التكاليف لعملية الثتل الآلى التئ.

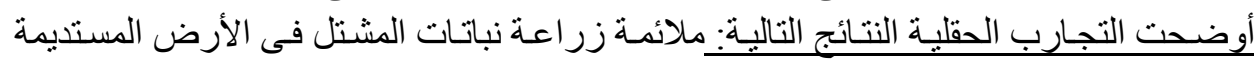

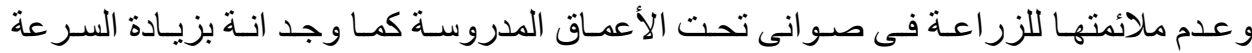

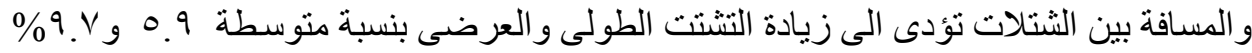

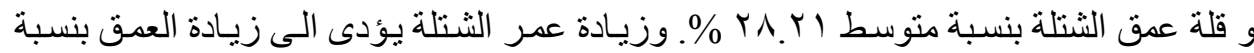

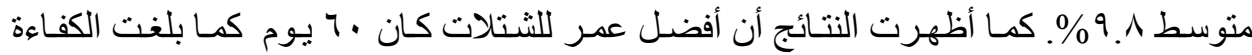

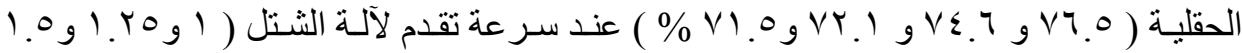

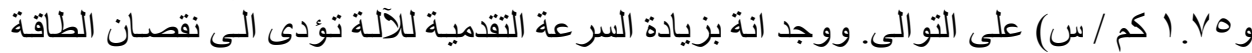

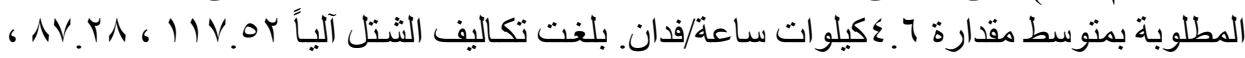

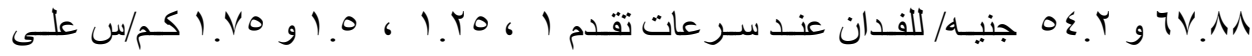

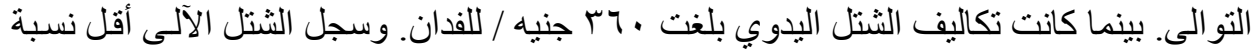

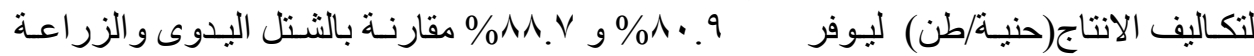

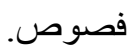

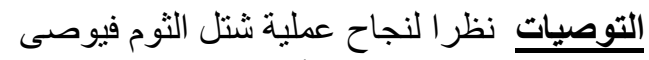

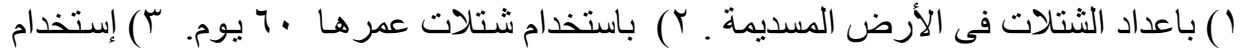

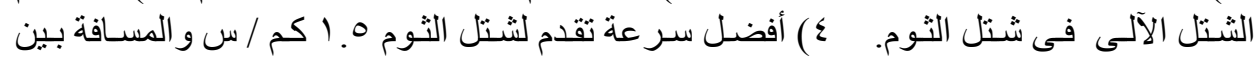

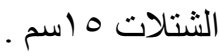

*قسم ميكنة المحاصيل الحقلية والبستانية ـ معهد بحوث الهندة الزراعية ـ مركز البحوث الزراعية الجيزة ـ مصر. 